\title{
Kombinasi Abu Kayu dan Kapur pada Proses Pengasinan terhadap Karakteristik Fisikokimia dan Nilai Organoleptik Telur Asin
}

\section{The Combination Ash Wood and Lime in The Salting Process Physicochemical Properties and Sensory Test Salted Eggs}

\section{Novia*, S. Melia dan Mutiara}

Fakultas Peternakan Universitas Andalas, Padang, 25163

E-mail: deni_novia@yahoo.co.id

(Diterima: 11 November 2015; Disetujui: 19 Januari 2016)

\begin{abstract}
ABSTRAK
Proses pengasinan akan mengubah telur itik menjadi telur dengan kandungan mineral, dan organoleptik yang meningkat. Tujuan dari penelitian ini adalah melihat pengaruh kombinasi abu kayu dan kapur pada proses pengasinan terhadap kadar kolesterol, $\mathrm{NaCl}$, kalsium, lemak, air, $\mathrm{pH}$, dan organoleptik telur asin. Penelitian ini menggunakan rancangan acak lengkap dengan lima perlakuan dan empat ulangan. Perlakuannya adalah kombinasi abu kayu dengan kapur : A (4-0), B (3-1), C (2-2), D (13) dan E (0-4). Berdasarkan hasil penelitian didapatkan bahwa kombinasi abu kayu dan kapur berpengaruh terhadap kadar $\mathrm{NaCl}$, kalsium, $\mathrm{pH}$ tetapi tidak berpengaruh nyata terhadap kadar lemak, air, dan nilai organoleptik. Perlakuan terbaik adalah kombinasi abu kayu dan kapur (2-2) dengan kadar $\mathrm{NaCl}$ $3,69 \pm 0,47 \%$, kalsium $1,72 \pm 0,06 \%$, lemak $13,94 \pm 1,28 \%$, air $70,96 \pm 0,92 \%$, pH $6,91 \pm 0,17$, warna 2,16 , aroma 2,24 dan rasa 2,20 (suka).
\end{abstract}

Kata kunci: abu kayu, fisikokimia, kapur, nilai organoleptik, telur asin

\section{ABSTRACT}

Salting process will transform duck eggs into the eggs with increased mineral content, and sensory test. The purpose of this study was to see the effect of the combination of wood ash and lime into the salting process on cholesterol, sodium chloride, calcium, fat, moisture, $\mathrm{pH}$ and sensory test salted eggs. This study used a completely randomized design with five treatments and four replications. The treatments were a combination of wood ash and lime: $A$ (4-0), B (3-1), C (2-2), D (1-3) and E (0-4). Based on the results that the ratio combination of wood ash and lime affected the levels of sodium chloride, calcium, $p H$ but did not affect the levels of fat, moisture, and sensory test. The best treatment was a combination of wood ash and lime (2-2) with a sodium chloride content of $3.69 \pm 0.47 \%$, calcium $1.72 \pm 0.06 \%$, fat $13.94 \pm 1.28 \%$, moisture $70.96 \pm 0.92 \%$, pH $6.91 \pm 0.17$, color 2.16 , aroma 2.24 and flavor 2.20 (like)

Keywords: lime, physicochemical properties, salted eggs, sensory test, wood ashes

\section{PENDAHULUAN}

Telur itik kurang disukai dari telur ayam karena memiliki aroma yang lebih amis, namun telur itik yang telah diolah menjadi telur asin akan memiliki cita rasa khas yang lebih disukai dengan kandungan mineral yang lengkap terutama kalsium. Konsumsi kalsium pada anak remaja masih kurang dari kebutuhan. Menurut Hardiansyah et al. (2008) rata-rata konsumsi kalsium remaja SMA adalah 568,54 $\pm 288,06$ mg sedangkan kebutuhannya sebanyak 1000 mg per hari. Kandungan kalsium putih telur $0,27 \%$ dan kuning telur $0,55 \%$ r (Forson et al., 2011). Menurut Novia et al. (2014) telur itik yang dibuat telur asin dengan metode perendaman menggunakan abu kayu dan sekam akan meningkatkan kandungan mineralnya. Pembuatan telur asin dapat dilakukan dengan dua metode yaitu perendaman umumnya dilakukan di daerah Sicincin dan pelapisan atau coating yang umumnya dilakukan di Brebes.

Proses pengasinan akan mempengaruhi komposisi telur asin yang dihasilkan 
diantaranya kandungan mineral, kolesterol, garam dan cita rasa telur asin. Menurut Novia et al. (2013) pengasinan menggunakan abu kayu metode perendaman menghasilkan telur asin dengan kadar kolesterol kadar kolesterol 78,83 sampai dengan 147,41 mg/dl.

Menurut Alma'arif et al. (2012) abu kayu mengandung makro molekul Kalsium dan Kalium yang kadarnya paling besar dari abu sekam. Senyawa-senyawa yang terkandung dalam abu kayu yaitu kalsium $3,56 \%$, magnesium $0,97 \%$, natrium $0,52 \%$, kalium 4,77\% dan silika 7,77\%. Kandungan silika akan mempengaruhi penyerapan komponen telur berupa kolesterol. Purawisastra (2011) mengatakan abu kayu memiliki kebasaan tertinggi dibandingkan abu pasar, abu bambu, abu sekam. Sifat ini akan mempengaruhi penyerapan mineral dari abu ke dalam telur itik selama proses pengasinan. Abu kayu mengandung 5,319,68\% kalsium oksida (Anggoro, 2005).

Sumber mineral lain yang juga digunakan sebagai bahan pengasinan adalah kapur. Kapur merupakan bahan dengan kandungan kalsium yang paling tinggi. Menurut Russhell (2007) kapur mengandung 98,8\% kalsium oksida, sehingga diharapkan dapat meningkatkan kadar kalsium dari telur asin. Berdasarkan karakteristik tersebut telah dilakukan penelitian dengan tujuan melihat pengaruh kombinasi abu kayu dan kapur pada proses pengasinan terhadap kadar kolesterol, $\mathrm{NaCl}$, kalsium, lemak, air, $\mathrm{pH}$, dan organoleptik telur asin.

\section{METODE}

Penelitian ini menggunakan telur itik Pitalah sebanyak 50 butir yang berasal dari peternak itik di Batu Busuk, Padang. Bahan lain yang digunakan adalah abu kayu, kapur, garam dan air. Peralatan yang digunakan adalah Atomic Absroption Spectrophotometer (AAS), batang pengaduk, labu soxhlet, cawan porselin, kapas, tisu, petridish, erlenmeyer, desikator, labu ukur, kertas saring sedang bahan kimia yang dibutuhkan adalah aseton, etanol, $\mathrm{H}_{2} \mathrm{O}, \mathrm{HCl}$ dan larutan benzen.
Penelitian ini menggunakan metode eksperimen dengan rancangan acak lengkap (RAL) terdiri dari lima perlakuan dan empat ulangan. Perlakuannya adalah kombinasi abu kayu dengan kapur: A (4-0), B (3-1), C (22), D (1-3) dan E (0-4).

Model matematika dari rancangan adalah:

Keterangan :

$$
\mathbf{Y i j}=\mu+\tau \mathbf{i}+\varepsilon \mathbf{i j}
$$

$\mathrm{i}=$ Banyak perlakuan $(\mathrm{A}, \mathrm{B}, \mathrm{C}, \mathrm{D}$, dan $\mathrm{E})$

$\mathrm{j}$ = Banyak ulangan (1, 2, 3 dan 4)

Yij= Nilai pengamatan pada perlakuan ke 1 , ulangan ke $\mathrm{j}$

$\mu=$ Nilai tengah umum

$\tau \mathrm{i}=$ Pengaruh taraf ke-i dari faktor S (1 dan 2)

عijk= Pengaruh sisa dari unit percobaan

Jika hasil sidik ragam berpengaruh nyata maka dilakukan uji lanjut Duncan's. Parameter yang diamati terhadap telur asin rebus adalah kadar kolesterol menggunakan AAS, kadar garam metode titrasi, kadar kalsium menggunakan AAS, kadar lemak dengan metode soxhletasi, kadar air metode oven, $\mathrm{pH}$ menggunakan $\mathrm{pH}$ meter dan organoleptik menggunakan uji hedonik 1-3 (tidak suka, suka, sangat suka) menggunakan 25 orang panelis agak terlatih. Penelitian telah dilaksanakan di Laboratorium Teknologi Hasil Ternak, Fakultas Peternakan Universitas Andalas.

Proses pembuatan telur asin sebagai berikut : a) Telur itik mentah sebanyak 50 butir, dicuci bersih. b) Sementara itu disiapkan bahan pengasinan yaitu air, garam abu kayu dan kapur, untuk perlakuan kombinasi abu kayu dengan kapur, A (4-0), $\mathrm{B}(3-1), \mathrm{C}(2-2), \mathrm{D}(1-3)$ dan $\mathrm{E}(0-4)$. c) Kemudian masing-masing telur itik dilapisi dengan adonan pengasinan dan diasinkan selama 8 hari. d) Setelah 8 hari dibuang lapisan pengasinan, kemudian dicuci dan direbus selama 30 menit. Telur asin yang dihasilkan dianalisis kadar kolesterol, $\mathrm{NaCl}$, kalsium, lemak, air, $\mathrm{pH}$ dan nilai organoleptik. 


\section{HASIL DAN PEMBAHASAN}

Penelitian kombinasi abu kayu dan kapur dalam pembuatan telur asin didapatkan hasil seperti pada Tabel 1 . Berdasarkan Tabel 1 terlihat bahwa hasil analisis keragaman kombinasi abu kayu dan kapur berpengaruh terhadap kadar kolesterol, $\mathrm{NaCl}$, kalsium dan $\mathrm{pH}$ telur asin rebus tetapi tidak berpengaruh terhadap kadar lemak dan air.

\section{Kadar Kolesterol}

Hasil kadar kolesterol telur asin penelitian berkisar antara $18,67 \pm 2,08$ sampai $26,00 \pm 5,29 \%$ (Tabel 1). Kadar kolesterol perlakuan A berbeda nyata dengan perlakuan B, C, tetapi berbeda tidak nyata dengan perlakuan $\mathrm{D}$ dan E. Seiring dengan kombinasi kapur yang meningkat dalam adonan pengasinan akan menurunkan kadar kolesterol. Kapur tidak mengandung adsorben seperti silika pada abu kayu sehingga penyerapan kolesterol rendah menyebabkan kadar kolesterol lebih tinggi. Sehingga tanpa kombinasi kapur dihasilkan kadar kolesterol telur asin paling rendah.

Rendahnya kadar kolesterol pada perlakuan A disebabkan pada perlakuan A (abu kayu 100\%), abu kayu mengandung adsorben yaitu silika. Menurut Torelli et al. (2003) kandungan silika dari abu kayu yaitu 0,66 - 0,95\%. Adsorben akan menyerap kolesterol dari telur asin selama proses pengasinan. Penyerapan kolesterol dipengaruhi oleh $\mathrm{pH}$, semakin rendah $\mathrm{pH}$ maka kolesterol semakin tinggi. Said et al. (2012) mengatakan bahwa silika befungsi sebagai adsorben. Silfia (2015) menambahkan, silika dapat menurunkan kolesterol minyak jelantah 17,09\%.

\section{Kadar $\mathbf{N a C l}$}

Rataan kadar $\mathrm{NaCl}$ telur asin rebus hasil penelitian berkisar antara 3,10 $\pm 0,43 \%$ sampai dengan $4,03 \pm 0,24 \%$ seperti terlihat pada Tabel 1. Kadar $\mathrm{NaCl}$ terendah terdapat pada perlakuan D (kombinasi abu kayu dan kapur, 1:3). Hasil uji lanjut Duncan's perlakuan A berbeda tidak nyata dengan perlakuan $\mathrm{B}, \mathrm{C}$ dan $\mathrm{E}$ tetapi berbeda nyata dengan perlakuan D. Seiring dengan semakin menurunnya jumlah abu kayu yang digunakan dalam pengasinan akan menurunkan kadar $\mathrm{NaCl}$ namun penggunaan kapur $100 \%$ menyebabkan penyerapan $\mathrm{NaCl}$ maksimal. Abu kayu dan kapur berfungsi sebagai media pengasinan yang akan mengoptimalkan penyerapan $\mathrm{NaCl}$ secara bertahap. Menurut Alma'arif et al. (2012) senyawa-senyawa yang terkandung dalam abu kayu yaitu $\mathrm{Ca} 3,56 \%, \mathrm{Mg} 0,97 \%, \mathrm{Na}$ 0,52\%, K 4,77\% dan Si 7,77\%.

Menurut Kaewmanee et al. (2009) metode pengasinan pelapisan dan perendaman dengan lama pengasinan yang berbeda akan menurunkan kadar air dan meningkatkan kadar garam baik pada putih dan kuning telur. Sejalan dengan Hasil penelitian Kaewmanee, et al. (2011) peningkatan lama pengasinan akan menurunkan kadar garam telur asin rebus baik pada putih maupun kuning telur.

Rendahnya kadar $\mathrm{NaCl}$ perlakuan $\mathrm{D}$ (kombinasi abu kayu dan kapur, 1-3) sejalan dengan kadar kalsium yang juga rendah. Hal ini dipengaruhi oleh $\mathrm{pH}$ adonan pengasinan perlakuan D yang paling rendah. Perlakuan

Tabel 1. Kadar $\mathrm{NaCl}$, kalsium, lemak, air dan $\mathrm{pH}$ telur asin hasil penelitian.

\begin{tabular}{ccccccc}
\hline $\begin{array}{c}\text { Perlakuan } \\
\text { kombinasi abu } \\
\text { kayu - kapur }\end{array}$ & $\begin{array}{c}\text { K.Kolesterol } \\
(\%)\end{array}$ & $\begin{array}{c}\text { K. NaCl } \\
(\%)\end{array}$ & $\begin{array}{c}\text { K. Kalsium } \\
(\%)\end{array}$ & $\begin{array}{c}\text { K. Lemak } \\
(\%)\end{array}$ & $\begin{array}{c}\text { K. Air } \\
(\%)\end{array}$ & pH \\
\hline A (4-0) & $18,67 \pm 2,08^{\mathrm{b}}$ & $3,79 \pm 0,39^{\mathrm{a}}$ & $1,59 \pm 0,08^{\mathrm{b}}$ & $13,82 \pm 0,50$ & $70,00 \pm 0,34$ & $7,43 \pm 0,24^{\mathrm{a}}$ \\
B (3-1) & $26,00 \pm 5,29^{\mathrm{a}}$ & $3,91 \pm 0,42^{\mathrm{a}}$ & $1,45 \pm 0,04^{\mathrm{c}}$ & $13,98 \pm 0,77$ & $70,62 \pm 0,45$ & $7,08 \pm 0,08^{\mathrm{b}}$ \\
$\mathrm{C}(2-2)$ & $26,00 \pm 5,20^{\mathrm{a}}$ & $3,69 \pm 0,47^{\mathrm{a}}$ & $1,72 \pm 0,06^{\mathrm{a}}$ & $13,96 \pm 1,28$ & $70,96 \pm 0,92$ & $6,90 \pm 0,17^{\mathrm{b}}$ \\
D (1-3) & $25,00 \pm 3,61^{\text {ab }}$ & $3,10 \pm 0,43^{\mathrm{b}}$ & $1,53 \pm 0,09^{\mathrm{bc}}$ & $13,76 \pm 1,48$ & $71,17 \pm 1,85$ & $6,95 \pm 0,16^{\mathrm{b}}$ \\
E (0-4) & $22,67 \pm 3,51^{\text {ab }}$ & $4,03 \pm 0,24^{\mathrm{a}}$ & $1,63 \pm 0,06^{\mathrm{ab}}$ & $13,38 \pm 1,26$ & $71,21 \pm 0,79$ & $7,05 \pm 0,02^{\mathrm{b}}$ \\
\hline
\end{tabular}

Keterangan: Rataan dengan superskrip huruf kecil yang berbeda pada kolom yang sama menunjukan berbeda nyata $(\mathrm{P}<0.05)$. 
A memiliki pH 12,75 sedangkan perlakuan B 12,56, perlakuan C 12,62, perlakuan D 12,66 dan $\mathrm{pH}$ perlakuan E 12,70 . Kadar garam pada perlakuan D lebih tinggi dari hasil penelitian Budiman et al. (2012) kadar garam telur asin rebus yang telah disangrai 10 menit memiliki kadar garam putih telur $1.99 \%$ dan kuning telur $0.91 \%$ (rata-rata $1.45 \%$ ). Rendahnya kadar garam pada perlakuan ini dari perlakuan lainnya dipengaruhi penurunan proses difusi $\mathrm{NaCl}$ ke dalam telur disebabkan oleh $\mathrm{pH}$. Menurut Peck et al. (2008) proses difusi pasif dapat berlangsung tanpa ionisasi ataupun ionisasi, yang dipengaruhi oleh $\mathrm{pH}$.

Perlakuan E (kombinasi abu kayu dan kapur, 0-4) berbeda tidak nyata dengan perlakuan A, B dan C. Hal ini disebabkan oleh $\mathrm{pH}$ dan difusi $\mathrm{NaCl}$ paling optimal pada perlakuan ini yang bersumber dari kapur $100 \%$. Hasil penelitian Mahayana dan Hidayati (2011) media pengasinan yang paling cepat penyerapan $\mathrm{NaCl}$ berturut-turut adalah pasir (porositas paling tinggi), serbuk gergaji, bata merah dan tanah liat dengan waktu pemeraman 8 hari. Lukito et al. (2012) menambahkan bahwa telur puyuh yang diasinkan selama 5 hari dengan larutan garam jenuh mempunyai kadar $\mathrm{NaCl}$ lebih tinggi dari pelumuran adonan garam dengan abu gosok.

\section{Kadar Kalsium}

Berdasarkan analisis Duncan's perlakuan $\mathrm{C}$ berbeda tidak nyata dengan perlakuan $\mathrm{E}$ tapi berbeda nyata dengan perlakuan A, B dan D (Tabel 1). Tingginya kadar kalsium pada perlakuan $\mathrm{C}$ $(1,72 \pm 0,06 \%)$ dan $\mathrm{E}(1,63 \pm 0,06)$ sejalan dengan kadar garam yang dipengaruhi oleh proses difusi dari media pengasinan yaitu abu kayu, kapur (2-2), ke dalam telur. Kadar kalsium telur itik mentah lebih rendah dari kalsium abu dan kapur menyebabkan proses difusi berlangsung dengan baik. Russhell (2007) menyatakan kapur mengandung 98,8\% kalsium oksida. Menurut Forson et al. (2011) telur itik mengandung $0,27 \%$ kalsium pada putih telur dan $0,55 \%$ pada kuning telur. Hasil penelitian Novia et al. (2014) kadar kalsium abu kayu sebesar $1.22 \%$ dan pengasinan menggunakan larutan abu kayu 1 bagian, menghasilkan telur asin mentah dengan kadar kalsium 1,40\%.

\section{Kadar Lemak}

Kadar lemak dari telur itik yang diasinkan menggunakan kombinasi abu kayu dan kapur berpengaruh tidak nyata terhadap kadar lemak. Hal ini disebabkan oleh abu kayu dan kapur yang ditambahkan dalam adonan pengasinan mengandung persenyawaan yang sama dan tidak mengandung lemak. Penyerapan lemak tidak terjadi perbedaan pada perbandingan media pengasinan abu kayu dan kapur. Menurut Handayani (2012) abu kayu mempunyai senyawa $\mathrm{P}_{2} \mathrm{O}_{5}, \mathrm{~K}, \mathrm{Ca}$ dan $\mathrm{Mg}$ dan unsur hara mikro $\mathrm{Mn}, \mathrm{Cu}$ dan $\mathrm{Zn}$. Russhell (2007) menyatakan, kapur mengandung kalsium oksida (CaO) $98,8 \%$ dan $0,95 \%$ magnesium oksida.

\section{Kadar Air}

Hasil analisis keragaman kadar air telur asin sejalan dengan kadar lemak telur asin rebus yaitu berpengaruh tidak nyata. Hal ini disebabkan proses pengasinan menggunakan kombinasi abu kayu dan kapur yang mengandung senyawa yang hampir sama membuat penyerapan air dan proses osmosis belum mempengaruhi kandungan air telur asin rebus masing-masing perlakuan.

Berbeda tidak nyatanya kadar air juga disebabkan oleh persenyawaan garam kalsium yang terbentuk antara abu kayu, kapur dan kombinasinya jumlah molekul yang dihasilkan sama, sehingga perlakuan tidak ada yang menonjol atau higroskopis. Menurut Justiana dan Muchtaridi (2009) kalsium pada abu kayu dan kapur berikatan dengan air menghasilkan kalsium hidroksida, dan berikatan dengan garam dapur menghasilkan kalsium klorida $\left(\mathrm{CaCl}_{2}\right)$. Hasil penelitian Nurhidayat et al. (2013) kadar air dari telur asin direbus, dikukus, dioven, direbus yang dikombinasikan dioven dan dikukus berkisar antara 70,15 sampai $72,38 \%$. 


\section{pH Putih Telur}

Tabel 1 dapat dilihat bahwa rataan $\mathrm{pH}$ putih telur asin rebus berkisar antara $6,90 \pm 0,17$ sampai dengan 7,43 $\pm 0,24$. Uji lanjut Duncan's pH perlakuan A berbeda nyata dengan perlakuan lainnya. Rendahnya $\mathrm{pH}$ perlakuan A sejalan dengan paling tingginya kadar kalsium telur asin rebus yang dihasilkan. Hasil penelitian, menunjukkan bahwa adanya kapur dalam adonan pengasinan akan menurunkan $\mathrm{pH}$ putih telur asin rebus yang dihasilkan.

Tingginya $\mathrm{pH}$ putih telur pada perlakuan A (abu kayu 100\%) disebabkan $\mathrm{pH}$ kandungan $\mathrm{pH}$ abu kayu yang juga lebih tinggi dari kapur. Abu kayu yang digunakan dalam penelitian dengan $\mathrm{pH}$ 12,96 dan kapur 12,85. Sejalan dengan $\mathrm{pH}$ adonan pengasinan perlakuan A yang juga tinggi yaitu 12,75 sedangkan perlakuan B 12,56, perlakuan $\mathrm{C} 12,62$, perlakuan $\mathrm{D} 12,66$ dan $\mathrm{pH}$ perlakuan E 12,70.

Proses pengasinan menggunakan kombinasi abu kayu dan kapur dapat mempertahankan mutu telur itik asin karena mempertahankan peningkatan $\mathrm{pH}$. Peningkatan $\mathrm{pH}$ disebabkan oleh kandungan $\mathrm{CO}_{2}$ dalam telur. Hasil penelitian Wulandari (2004) nilai $\mathrm{pH}$ putih telur hasil perendaman dengan tekanan lebih rendah dibandingkan $\mathrm{pH}$ putih telur hasil perendaman tanpa tekanan. Berkurangnya $\mathrm{CO}_{2}$ yang terdapat di dalam telur menyebabkan terjadinya peningkatan $\mathrm{pH}$.

\section{Nilai Organoleptik}

Berdasarkan hasil penelitian kombinasi abu kayu dan kapur berpengaruh tidak nyata terhadap nilai organoleptik warna, aroma dan rasa. Lebih jelasnya seperti terlihat pada Gambar 1. Rataan organoleptik warna adalah 2,00 sampai dengan 2,32, dengan arti suka, aroma 2,08 2,28 yang berarti suka dan rasa 1,52 - 2,20 (suka).

Kombinasi abu kayu dan kapur belum mempengaruhi penilaian organoleptik telur asin yang dihasilkan sehingga hasil analisis keragaman berbeda tidak nyata. Berbeda tidak nyatanya penilaian organoleptik yang dihasilkan disebabkan oleh proses difusi yang terjadi selama proses pengasinan berupa garam-garam mineral saja, sedangkan warna dari media pengasinan tidak masuk ke dalam. Menurut Peck et al. (2008) proses difusi adalah metode untuk menyeberangi membran sel dari kosentrasi tinggi ke kosentrasi rendah dan tidak memerlukan energi. Sejalan denga penelitian Suryatno et al. (2012) pembuatan telur asin dengan media pengasinan batu bata merah : abu gosok : garam dapur (2:1:1) yang dibungkus 1-1,5 cm, warna telur asin hampir sama (cenderung netral bahkan agak suka) untuk lama pemeraman 7-20 hari.

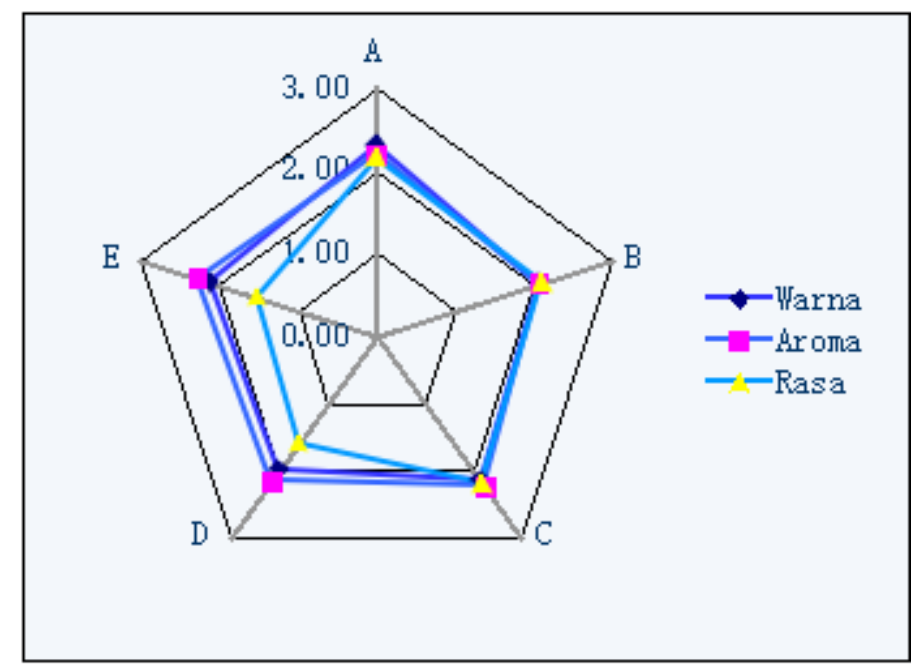

Gambar 1. Nilai organoleptik warna, aroma dan rasa telur asin rebus hasil penelitian. 
Hasil penelitian Mahayani dan Hidayati (2011) tingkat kesukaan konsumen terhadap produk telur asin yang paling tinggi adalah pada media bata merah (lama pemeraman 12 hari), kemudian diikuti serbuk gergaji, pasir dan tanah liat.Berbeda tidak nyatanya rasa telur itik asin pada penelitian ini berbanding lurus dengan kadar lemak yang berbeda tidak nyata. Sejalan dengan pendapat Winarno (2004) bahwa lemak dari bahan pangan dapat memperbaiki cita rasa dari bahan pangan. Djaafar (2007) menambahkan bahwa lemak dalam telur berfungsi meningkatkan cita rasa.

Hasil uji organoleptik terhadap rasa telur itik asin menunjukkan bahwa berbagai perlakuan kombinasi abu kayu dan kapur termasuk kriteria suka. Rasa suka disebabkan oleh garam-garam mineral yang terdapat pada media pengasian yang berdifusi kedalam cangkang telur.

\section{KESIMPULAN}

Berdasarkan hasil penelitian didapatkan bahwa kombinasi abu kayu dan kapur berpengaruh terhadap kadar garam, kalsium, $\mathrm{pH}$ tetapi tidak berpengaruh terhadap kadar lemak, air, dan nilai organoleptik. Perlakuan terbaik adalah kombinasi abu kayu dan kapur (2-2) dengan kadar $\mathrm{NaCl} 3,69 \pm 0,47 \%$, kalsium $1,72 \pm 0,06 \%$, lemak $13,94 \pm 1,28 \%$, air $70,96 \pm 0,92 \%, \mathrm{pH} 6,91 \pm 0,17$, warna 2,16 , aroma 2,24 dan rasa 2,20 (suka).

\section{DAFTAR PUSTAKA}

Alma'arif, A.L., A.Wijaya dan R.P.D. Murwono. 2012. Penghilangan racun asam sianida (HCN) dalam umbi gadung dengan menggunakan bahan penyerap abu. Jurnal Teknologi Kimia dan Industri. 1(1):14-20.

Anggoro, D.D. 2005 Aktifitas dan pemodelan katalis silikat dari abu sekam padi untuk konveksi hexana. Reaktor 9(1):1-7.

Budiman, A., A. Hintono dan Kusrahayu. 2012. The Effect of "Penyangraian" of salted eggs after boiling to the natrium chloride content, saltiness and elasticity. Animal Agricultural Journal. 1(2): 219-227.

Djaafar, T.F. 2007. Telur asin omega-3 tinggi. Warta Penelitian dan Pengembangan Pertanian 29(4):4-5.

Forson, A., Z.J.E. Axivor, E.K. Banini., C. Nuviadenu and S.K. Debrah. 2011. Evaluational some elemental variation in raw egg yolk and egg white of domestic chicken, guinea, fowl and duck eggs. Annals of Biological Research. 2(6) : 676-680.

Handayani, I.P. 2012. Studi pemanfaatan gambut asal Sumatera : Tinjauan fungsi gambut sebagai bahan ekstraktif, media budidaya dan peranannya dalam retensi carbon. Wetlands International. Pages : 219 232.

Hardinsyah, Damayanthi, Zulyanti. 2008. Hubungan konsumsi susu dan kalsium dengan densitsas tulang dan tinggi badan remaja. Jurnal Gizi dan Pangan. 3(1):43-48.

Justiana, S., dan Muchtaridi. 2009. Kimia 3. Yudhistira. Jakarta Timur.

Kaewmanee, T., S. Benjakul dan W. Visessanguan. 2009. Effect of salting processes on chemical composition, textural properties and microstructure of duck egg. Journal of the Science of Food and Agriculture. 89(4) 4 : 625633. Doi:10.1002/jsfa.3492.

Kaewmanee, T., S. Benjakul and W. Visessanguan. 2011. Effect of salting processes and time on the chemical composition, textural properties and microstructure of cooked duck egg. Journal of Food Science. 76(2): S139S147. Doi: 10.1111/j.1750-3841.2010.01975.x.

Lukito, G.A., A.Suwarastuti dan A. Hintono. 2012. Pengaruh berbagai metode pengasinan terhadap kadar $\mathrm{NaCl}$, kekenyalan dan tingkat kesukaan konsumen pada telur puyuh asin. Animal Agriculture Journal, 1(1) : 829-838.

Mahayana, A dan N. Hidayati. 2011. Modifikasi teknologi pengasinan telur 
melalui pemanfaatan limbah serbuk gergaji dan pasir terhadap absorbsi $\mathrm{NaCl}$. Jurnal Kimia dan Teknologi. 7(1) : 15-21. ISSN 0216-163X.

Novia, D., S. Melia, dan I. Juliyarsi. 2013. Kadar kolesterol telur asin mentah hasil pengasinan dalam larutan abu. Prosiding Seminar Nasional Peranan Teknologi Pangan dan Gizi dalam Meningkatkan Mutu, Keamanan dan Kehalalan Produk Pangan Lokal. ISBN.978-602-96301-2-1. Hal : 234239.

S. Melia and I. Juliyarsi. 2014. Utilization of ash in the salting process on mineral content raw salted eggs. Asian J. Poult. Sci. 8(1):1-8

Nurhidayat, Y., J. Sumarmono, S. Wasito. 2013. Kadar air, kemasiran dan tekstur telur asin ayam niaga yang dimasak dengan cara berbeda. Jurnal Ilmiah Peternakan 1(3): 813-820

Peck, T., S. Hill and M. Williams. 2008. Pharmacology for anaesthesia and intensive care, section I. Drug Passage Across the Cell Membrane. Cambridge University Press. Hal : 17. ISBN 978-0-521-70463-2.

Purawisastra, S. 2011. Penggunaan beberapa jenis abu untuk isolasi senyawa galaktomanan dari ampas kelapa. Jurnal Riset Teknologi Pencegahan Pencemaran Industri. 1(4) : 260-266.
Russell. 2007. Apparatus and methods for producing calcium chloride and products made thereform. Patent. http:// www.patentsonline/US20070009423/.

Said. A., I. Fatimah, D. Rubiyanto. 2012. Effect of temperatire on rice husk asing and its application on adsorbing $\mathrm{Fe}$ and $\mathrm{Zn}$ metal in patchouli oil. J. Eksakta 14(2):71-86.

Silfia. 2015. Abu sekam padi untuk memperbaiki kualitas minyak jelantah. Thesis, Universitas Andalas.

Suryatno, H., Basito, E. Widowati. 2012. Kajian Organoleptik, Aktivitas Antioksidan, Total Fenol pada Variasi Lama Pemeraman Pembatan Telur Asin yang Ditambahkan Ekstrak Jahe (Zingiber officinale Roscoe). Jurnal Teknosains Pangan. 1 (1) : 118-125

Torelli, N., M. Piskur, V. Tisler. 2003. Wood species the central African Republic : Ash and silica content. Zbornik gozdarstva in lesarstva 72, s. 53 - 61.

Winarno, F.G. 2004. Kimia Pangan dan Gizi. Cet-11. Gramedia Pustaka Utama. Jakarta.

Wulandari, Z. 2004. Sifat fisikokimia dan total mikroba telur itik asin hasil teknik penggaraman dan lama penyimpanan yang berbeda. J.Media Peternakan. 27(2) : 38-45. ISSN 01260472. 